\title{
Impresiones sobre el nuevo Reglamento de Contratación
}

Lo más revolucionario del nuevo Reglamento es que se ha abandonado la teoría tradicional del contrato administrativo. Esta ha sido sustituída por la nueva concepción contractualista privada de los contratos administrativos, según la cual "contrato" y "administrativo" son en rigor conceptos antagónicos, porque todos los contratos celebrados por la Administración son idénticos. Por eso se regulan por igual toda clase de contratos de las Administraciones locales, se refieran o no a obras, bienes, servicios o suministros públicos.

Si la experiencia y la historia del Derecho local son cosas de las que uno puede derivar enseñanza, podemos calcular el período de vida de este Reglamento. La pr:mera mitad de nuestro siglo ha conocido ya cinco regulaciones de la materia de contratación : las de 1900, 1905, 1923, 1924 y 1935.

Es inútil pretender hallar una definición perfecta y estable de contrato administrativo. Cada autor tiene la suya. La de Fernández de Véasco no es la de Alvarez Gendín y la de Gastón Jeze 
no es la de Miguel Angel Berçaitz. Ha sido un acierto del Reglamento no darnos la noción del "contrato".

La causa de los contratos es cosa primordial. Ha de existir siempre. El Tribunal Supremo declaró-sentencia de 11 de febrero de 1911 -que no existía contrato por falta de causa en una convención concluída por un Ayuntamiento con una empresa para instalar unos postes, porque la Administración municipal nada ganaba ni se lucraba con la concesión gratuitamente concedida. Es un acierto, pues, del Reglamento haber señalado (art. $10^{\circ}$ ) la causa como elemento necesario para la validez del contrato.

Uno de los requisitos exigidos para la validez y eficacia de los contratos (art. $1 .^{\circ}$ ) es el relativo al cumplimiento de las formalidades. Las formas evitan decisiones irreflexivas y precipitadas. Las formas defienden a la Administración contra los errores y a los particulares contra la arbitrariedad.

La prescripción (párrafo 1 del art. $9 .^{\circ}$ ) de que la materia de los contratos no podrá fraccionarse en partes o grupos, si el pcríodo de ejecución correspondiere al de un solo Presupuesto ordinario, persigue una buena finalidad: la de evitar que un hábil fraccionamiento haga que la cuantía no llegue a la cifra que obliga a celebrar subasta, concurso-subasta o concurso; pero, lo que son las cosas, resulta que a la inversa, si la ejecución corresponde a varios-Presupuestos ordinarios, podrá fraccionarse la materia, y si es así, la disposición consigue lo contrario de lo que se propone.

Hay que repasar por lo menos tres veces un texto para que "salga bienn, y aun así muchas veces se escapan pequeñas defectuosi- 
dades. No es extraño que mientras el artículo 21 habla de condic:ones "jurídicas, técnicas y económicas", el artículo 22 hable de condiciones "facultativas y económico-administrativas"; ni es raro que el epígrafe del capítulo VI se tituie "Resolución, rescisión y: denuncia de los contratos", y luego en ninguno de los artículos que lo integran se hable de "rescisión".

No se podrá decir que el Reglamento no sea muy moderno $y_{i}$ progresivo. En materia de publicidad de las licitaciones ha ido mucho más allá que la anterior regulación. Se previenen inciuso cmisiones radiofónicas de lus anuncios de licitación (art. 26). ¿Cuánto costarán?

La disposición que permite la suspensión, por acuerdo corporativo, de las licitaciones anunciadas (art. 32) acaba muchas discusiones. Refleja la sana doctrina de que mientras no está perfeccionado el contrato no ha contraído la Administración obligación de fondo, y por ello puede desistir de llevar adelante la licitación. Ahora bien, "suspens:ón" no es "anulación"; es, simplemente, interrupción temporal.

Uno de los preceptos que más nos gustan es el que establece que sean públicos los actos de apertura de plicas (art. 33). Ello permite que tengan acceso al local donde tenga lugar el acto personas distintas all elemento oficial y a los proponentes. Somos unos enamorados de la publicidad de los actos.

Los reglamentos no pueden modificar las leyes. Sin cmbargo, el articulo 37, al enumerar con relación a la Ley cuatro casos nue- 
vos de excepción a la forma de subasta, extiende enormemente el campo de aplicación de las modalidades excepcionales. ¿No nos hallaremos, pues, en realidad, ante una modificación de la Ley más que ante un desenvolvimiento reglamentario de su artículo 310 ?

Por fin, la modalidad del concurso-subasta, uno de los más positivos enriquecimientos del Derecho local en materia de formas de contratación, ha sido regulada con el detalle necesario, y muy bien por cierto (art. 39). Forma prevista por la Ley de Bases de Régimen local (1945), no había sido más que apuntada por la Ley de Régimen local (1950) y su desenvolvimiento, para la debida aplicación, lo echaban de menos las Administraciones locales.

Se venía discutiendo si las Corporaciones, llegado el momento de la adjudicación, podían declarar desierto el concurso sin que los concurrentes pudieran combatir con éxito tal declaración. E1 inciso final del artículo 40 finiquita la cuestión : las Corporaciones podrán declarar desierto el concurso "si ninguno de lo concurrentes cumpliere las condiciones del pliegon.

E1 criterio del Tribunal Supremo-sentencia de 29 de octubre de 1932-en sentido de que ningún licitador tiene derecho a que su proposición si es única sea forzosamente aceptada, ya no puede prosperar. Conforme a lo dispuesto por el artículo 44, si la propuesta se ajusta al tipo fijado, o lo mejora, deberá hacerse la adjudicación a favor de su autor.

No abundábamos en la opinión que sostiene que las Administraciones locales llegado el trámite de adjudicación definitiva pro- 
ceden con piena facultad discreciona! para apreciar la validez o nuiidad del acto de la subasta. No éramos partidarios de que un Ayuntamiento o Diputación pudiera libremente, sin fundamento, declarar que no es válido un acto licitatorio celebrado $y$, consiguientemente, que tal discrecional pronunciamiento no pudiera ser combatido con éxito en la vía jurisdiccional contencioso-administrativa. Por ello, a nuestro juicio, es un acierto la redacción del texto del artículo 44, y especialmente el de su párrafo 1, en el que se ha suprimido la frase "lo procedente»-utilizada por el anterior Reglamento-al establecerse que "la Corporación contratante resolverá sobre la validez o nulidad del acto licitatorion.

Siempre es útil la labor de los conentaristas. Veamos una muestra : el texto del' artículo 47, sobre pago de anuncios y demás gastos por los contratistas. El comentarista de este precepto puede aclarar una serie de extremos, tales como estos: ¿Están obligadas las administraciones de los periódicos oficiales a la inserción de los anuncios de licitación sin mediar su previo pago por las Corporaciones locales? ¿Cuáles son en concreto los gastos que debe pagar el adjudicatario? ¿Quẻ gravamen hay por concepto de impuestos de Derechos reales y Timbre? ¿Qué tributará por concepto de contribución industrial el contratista? ¿ Pueden en algún caso los Secretarios percibir derechos $\mathrm{u}$ honorarios por sus intervenciones? ¿Quién debe pagar los gastos cuando el remate ha sido otorgado en segunda o posterior licitación? ¿Qué ocurre si el rematante no presta fianza definitiva o no concurre a la firma del documento contractual ?...

La batallona cuestión de si los funcionarios locales pueden percibir derechos u honorarios está muerta y enterrada muy hondo. La defunción y enterramiento han corrido a cargo del artículo 81 del Reglamento de Funcionarios de Administración local y del 
artículo 47 del Reglamento de Contratación de las Corporaciones locales, respectivamente. $Y$ por si alguien intenlare resucitarla, aún podemos esgrimir la Circular de la Dirección General de 23 de enero de 1953.

La excepción de privilegio al principio general de inalterabilidad de los contratos que establece a favor de la Admin:stración el artículo 51 nos recuerda aquel precepto de la Ley de lo Contencioso-administrativo que faculta al Cobierno para supender la ejecución de sentencias en casos de peligro para el orden público, y aquellas disposiciones de la Ley de Orden Público y de la Ley de Seguridad del Estado que estabiecen que las autoridades deben mantener el orden público y al efecto pueden adoptar las medidas pertinentes al abastecimiento y servicios necesarios de la población. El orden y la seguridad públicos son de mantenimiento inexcusable. Sin ellos no subsistiría el Estado. He ahí el fundamento del precepto.

Sería disparatado permitir al contratista que, basándose en el incumplimiento de una cláusula contractual, o en la falta de pago en la fecha convenida, o en cualquier otro motivo, pudiera interrumpir el suministro de vitales elementos a una población. Es por ello un buen precepto el del artículo 56. Creemos que quien sentís por primera vez, en forma razonada, el criterio, fué el Tribunal Supremo, en sentencia de 8 de febrero de 1894. La empresa del gas de Córdoba, fundándose en falta de pago por parte del Ayuntamiento, suspendió la prestación del servicio de suministro del gas para alumbrado público, como medio de obligar al Ayuntamienio a que le abonase lo que le debía por tal servic:o. El Tribunal consideró que no podía autorizarse a que una de las partes se tomase la justicia por su mano y, además, que de ello resultasen perjucicados los administrados, que ninguna culpa tienen de que sus administraciones no cumplan lo convenido.

La palabra "lesión" expresa la idea de que el contratista ha sufrido un perjuicio, y la frase "a riesgo y venturas significa que la 
lesión no es causa de rescisión y consiguientemente de indemnización. "A riesgo y ventura" quiere decir que el contratista, por ninguna causa, salvo las de fuerza mayor o caso fortuito expresamente previstas, podrá pedir alteraciones de precio, indemnizaciones o rescisión. Uno de los méritos del Reglamento es el de fijar con precisión las causas determinantes de lesión indemnizable. Todas las causas, eventos o sucesos no previstos, artículo 57, es riesgo inherente al negoc:o que va a cargo del contratista, en contrapartida del lucro o ganancia que el mismo normalmente ha de obtener del contrato.

Queda bien claramente establecida la posibilidad de que la Administración prorrogue los contratos de obras (art. 58). Las anteriores regulaciones no admitieron las prórrogas, por estimar que inciden en la doctrina de la novación y comportan la modificación de uno de los requisitos esenciales del contrato: su duración. Creemos, empero, que no es admisible la próroga pactada que equivaldría a suprimir las garantías que la Ley exige y que las Corporaciones locales no pueden dejar de cumplir al concertar los contratos.

Las garantías, fianzas o depósitos no pertenecen a la Entidad contratante, ni constituyen ingreso de su Presupuesto mientras no llega el caso de tener que incautarse de ellos la Corporación para hacer efectivas multas, indemnizaciones y responsabilidades del contratista. El quebrantamiento de depósito constituye delito de malversación de caudales públicos.

Con la modalidad de garantía personal ha ocurrido algo curioso. La primera disposición reguladora de la materia-Real Decreto de 4 de enero de 1883 - estableció, entre las posibles formas de 
fianza, la garantía personal ; pero, luego, las disposiciones posteriores-Instrucciones de 1900, 1905 y 1923 y Reglamento de 2 de junio de 1924-suprimieron tal modalidad. El nuevo Reglamento, artículo 79 , revive la garantía personal.

Observamos la diferencia de trato entre las garantías provisionales y las definitivas cuando se constituyen en la Caja General de Depósitos o en sus sucursales. Las provisionales pueden constituirse en cualquier lugar (en Madrid, en Cádiz, en Bilbao, en Cáceres, en Gerona), cualquiera que sea la población donde haya de celebrarse la licitación, es decir, que si se trata, por ejemplo, de subasta anunciada por la Diputación de Badajoz, puede constituirse la garantía en la Caja General de Depósitos de la Delegación de Hacienda de Barcelona. Las garantías definitivas, en cambio, hay que constituirlas precisamente en la misma provincia en que radique la Entidad contratante (art. 77).

Se ha dado una gran personalidad a los técnicos. La recepción provisional es formalizada por acta firmada por el correspondiente técnico y el contratista (art. 61). La Administración está representada por el técnico en dicho acto. Los Arquitectos e Ingenieros pueden estar contentos.

Se proclama el principio de la inembargabilidad de las garantías (art. 91). Nos parece muy bien el precepto. Recordamos que ni la Ley de Régimen local, ni el Reglamento de Haciendas locales, ni ningún otro precepto del Derecho positivo local declara la inembargabilidad de los bienes de los Ayuntamientos y Diputaciones, y por ello, para mantenerla, hay que acudir a la Ley de Administración y Contabilidad de la Hacienda Pública (art. 15) o al Esta- 
tuto de Recaudación (arts. 82 y 83), que no exceptúan del embargo las garantias de los contratistas con la Provincia y el Municipio.

Es un privilegio y una gran ventaja no tener que acudir la Administración al Juzgado para poder hacer efectivas las responsabilidades del contratista (art. 98). Bastará el acuerdo corporativo y, en su caso, la certificación de débito y la providencia de apremio, para proceder contra los bienes del contratista.

No ligan del todo bien los artículos 97 y 98 . Del primero parece desprenderse que la pérdida de la garantía es una sanción penal independiente y sin relación con la cuantía del perjuicio ocasionado por el contratista a la Administración, y, en cambio, del segundo parece deducirse lo contrario, o sea, que agotada la garantía sólo podrá procederse contra los demás bienes del contratista por la diferencia entre el montante de aquélla y el importe total de la responsabilidad que legalmente haya sido declarada. Por ello abrimos este interrogante : ¿El importe de la garantía objeto de incautación y aplicación rebajará o no la cuantía de la inciemnización fijada en concepto de daños y perjuicios?

Al examinar el artículo 99, nos preguntamos: ¿ Es acertado y justo disponer que en un contrato concluído entre dos partes-contratista y Administración-una de estas partes, la Administración, sea la que interprete y resuelva las dudas que ofrezca su cumplimiento? Y nuestra contestación es la de que sí que es acertado y justo. ¿Por qué? Pues, porque de lo que se trata es de que se aplique la Ley-que es el Pliego de condiciones-en la forma y en el sentido en que el autor de las normas quiso que fueran aplicadas; y para ello la interpretación en su desarrollo ha de seguir el camino opuesto al del perfeccionamiento del contrato. La idea que tuvo la Administración al redactar el Pliego de condiciones pasó por una serie de vicisitudes hasta llegar a obtener la forma gramatical en 
que quedó redactado el contrato. Pues bien, el que interpreta el contrato ha de seguir el camino a la inversa : partir de la letra e ir a parar a la idea primitiva del redactor de las cláusulas contráctuales. Y quien puede operar así es únicamente la propia Administración, pues ésta y no el contratista es la que tuvo la idea, elaboró la proyección y confeccionó la norma jurídica contractual.

Las sentencias del Tribunal Supremo son a a veces curiosísimas. Veamos un caso: la sentencia de 20 de octubre de 1893. El Ayuntamiento de Madrid contrató el servicio de incendios, estableciéndose las multas y responsabilidades en que incurriría el contratista por las infracciones que cometiera de lo estipulado. Simulóse un gran incendio por disposición del Alcalde, y acudieron las bombas de que disponla el contratista, tarde y sin agua la mayor parte de ellas, conducidas por mulas inútiles, etc. La Alcaldía impuso al contratista multas correspondientes a las faltas advert:das. El Gobernador revocó en alzada estas multas y el Tribunal provincial mantuvo la revocación, pero el Tribunal superior revocó a su vez la sentencia del provincial y declaró firme y subsistente el acuerdo del Alcalde considerando que la circunstancia de haberse comprobado las faltas en un simulacro de incend:o no es de apreciar, porque los simulacros son debidos y constituyen el med:o más eficaz de prueba de la exactitud y puntualidad en el servicio.

Se ha soslayado hábilmente concretar en cada caso cuál es el órgano competente para el acto (de aprobación de pliegos, de adjudicación, de suspensión de licitación). Se habla s:empre de "Corporación". No se precisa si la competencia radica en el Ayuntamiento pleno o en la Comisión permanente; en la Diputación o en su Presidente. En cada caso, para saber quién tiene la competencia, habrá de acudirse a los correspondientes preceptos de la Ley de 
Régimen local y del Reglamento de organización, funcionamiento $\mathrm{y}$ régimen jurídico de las Corporaciones locales.

La exaltación de la idea de comunidad, el intervencionismo estatal y la subordinación de la Administración a la Política, han producido una crisis del contrato-magníficamente tratada por Perez Serrano en su conferencia sobre el nuevo sentido del contrato--. Confiamos en que esta crisis, fenómeno que se da en todos los países, será pasajera y circunstancial.

Luis Marqués Carbó

Doctor en Derecho

Secretario de Administración Loc 